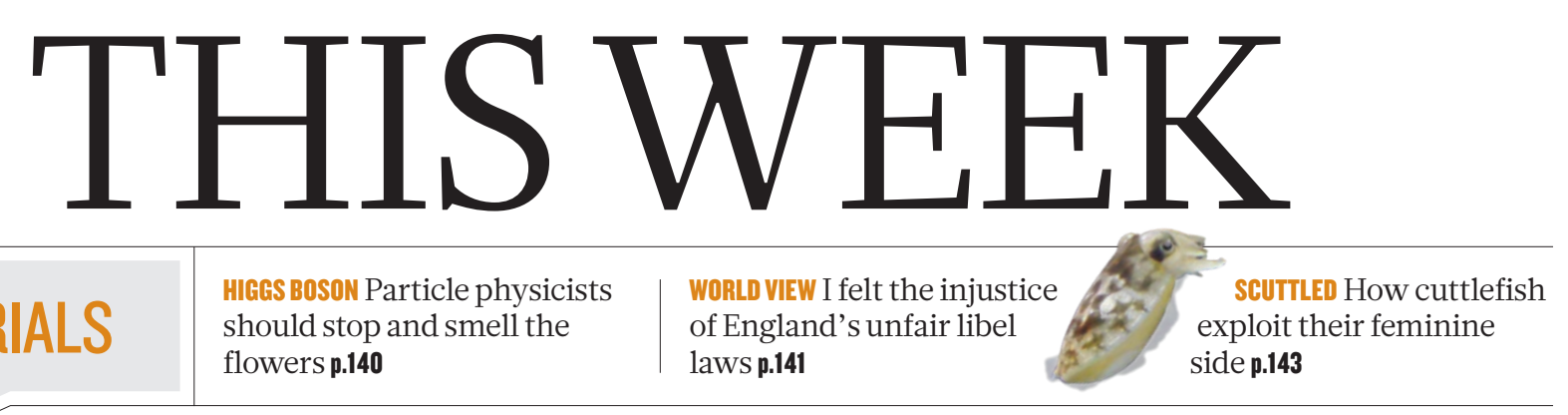

EDITORIALS

should stop and smell the flowers p.140 injustice laws p.141 exploit their feminine

side $\mathbf{p} \mathbf{1 4 3}$

\title{
Victory for responsible reporting
}

\author{
A High Court case highlights the inadequacies of England's libel laws and should be used as an \\ impetus for major reform.
}

$\mathrm{F}$ or more than three years, Nature Publishing Group and Nature reporter Quirin Schiermeier have been fighting a libel claim brought by physicist and engineer Mohamed El Naschie. The defence cost around $£ 1.5$ million (US $\$ 2.3$ million) in legal fees and gobbled up weeks of the time of several employees. Last week, a judge ruled that it was time and money well spent. El Naschie's libel claim was so weak that the judge conceded not a single point to the plaintiff. The Nature article in question, her 91-page ruling declared, was "responsible journalism", accurate in every key detail, and its publication was "of high order of public interest" (see page 149).

The judgment is welcome vindication for Schiermeier, Nature and for good journalism. It upholds the importance of stories that probe bad practices in science - in this case, El Naschie's abuse of his position as editor of a journal to publish his own papers without peer review. But as Schiermeier says (see page 141), the legal victory has even more significance. It should give additional impetus and backing to a campaign to rewrite the antiquated libel laws of England and Wales, which contributed to making El Naschie's feeble claim so difficult and expensive to fight.

Many in the United Kingdom rightly consider the libel laws a national embarrassment, and politicians have vowed to change them. At present, as Nature has pointed out before, the laws tip the scales so far towards the plaintiff - by forcing defendants to prove the truth of all allegations, rather than plaintiffs to prove the falsehood - that London has become a playground for foreign corporations and celebrities who seek to use the courts to burnish their reputations.

Powerful groups and individuals routinely use the threat of a libel suit to deter consumer and advocacy organizations from speaking out about bad products and practices. And the plaintiff-friendly law has had a chilling effect on scientific debate and on journalism. It means that publications such as Nature must perform a painful calculation every time an important but legally sensitive story comes along: is it worth the risk? Nature's victory shows that you can win when your case is strong, but that takes more stamina and deeper pockets than many organizations can muster. And, much as Nature was determined to fight for good journalism and free speech in this case, a fear of the libel laws has in the past forced us to not report stories that we knew to be true and in the interest of our readers and society.

Now some relief is in sight. The three major political parties in the United Kingdom support libel reform, and a bill to change the law is working its way through Parliament. The bill includes welcome measures, such as protection for peer-reviewed publications and for discussions at scientific conferences. But for journalism, such as Nature's article on El Naschie, the reform does not go far enough. It extends the existing Reynolds defence, which gives limited protection for reporting that can be shown to be in the public interest and meets a series of other requirements. But winning a case on 'Reynolds' one of several grounds on which Nature prevailed - is expensive and

difficult. Giving the public-interest defence broader scope would deter weak claims that stifle free speech and would allow judges to dismiss meritless complaints earlier in the process - to the benefit of all.

There is still time to make such a change. The bill will undergo fresh rounds of debate and revision later this year. The Libel Reform Campaign, which Nature supports, is urging lawmakers to add a clause that protects stories in the public interest from libel claims unless the reporters have published falsehoods recklessly or maliciously. Its
"The judgment upholds the importance of stories that probe bad practices in science." aggrieved individuals to sue and win. But it would also free brave and principled reporters such as Schiermeier to expose misbehaviour — journalism that is clearly in the public interest - knowing that if their reporting is thorough and fair, they are unlikely to have to go through a similar ordeal.

\section{Take a stand}

\section{Legal actions and oversight are necessary to keep the drug industry in line.}

$\mathrm{P}$ harmaceutical giant GlaxoSmithKline (GSK) agreed last week to settle criminal and civil claims by paying the US authorities a stunning US $\$ 3$ billion. It is the largest drug-industry settlement in history; the allegations include that the company ran illegal campaigns to promote the prescription of drugs for unapproved uses in children, and published "false and misleading" accounts of clinical studies.

According to the US complaint, GSK also lavished some doctors and academics with "sham consulting fees" and other payments, as well as gifts and attendance at luxury conferences in venues such as Bermuda and Jamaica - sometimes with sailing or deep-sea fishing thrown in - to encourage them to prescribe drugs for off-label uses (see go.nature.com/dbhkht). Speakers could earn $\$ 1,000-2,500$ per hour to talk at promotional events, with some negotiating 'six packs' of $\$ 12,000$-worth of talks over two days. One speaker earned about $\$ 1.5$ million between 2001 and 2003. Nice work if you can get it and too many could. Andrew Witty, chief executive of GSK, last week 